\title{
Occurrence of Bacterial Spot on Pumpkin and Squash Fruit in the North Central Region of the United States and Bacteria Associated with the Spots
}

Qiong Liu, Abbasali Ravanlou, and Mohammad Babadoost, Department of Crop Sciences, University of Illinois at Urbana-Champaign, Urbana 61801

\begin{abstract}
Liu, Q., Ravanlou, A., and Babadoost, M. 2016. Occurrence of bacterial spot on pumpkin and squash fruit in the north central region of the United States and bacteria associated with the spots. Plant Dis. 100:2377-2382.

Since 2006, a bacterial spot disease has been widely observed on pumpkin and squash fruit in the North Central region (NCR) of the United States. Surveys were conducted during 2011 to 2013 to determine the occurrence of the disease on pumpkin and winter squash in the NCR. In each state, at least five commercial pumpkin and squash fields were visited each year within 3 weeks of harvest, and 60 fruit were inspected in each field. In nine states surveyed, 217 of 245 fields had fruit with bacterial spot. The average incidence of the symptomatic fruit in all pumpkin fields surveyed was $27.1,30.3$, and $25.3 \%$ in 2011,2012 , and 2013, respectively. The average incidence of fruit with bacterial spot in all squash fields surveyed was $20.2 \%$ in 2012 and $16.9 \%$ in 2013 . The incidence of symptomatic fruit was more than $90 \%$ in some fields. Xanthomonas

cucurbitae and non-X. cucurbitae bacteria were isolated from all of the symptomatic fruit collected. X. cucurbitae was identified based on colony characteristics on yeast extract-dextrose- $\mathrm{CaCO}_{3}$ agar, a polymerase chain reaction test using primers RST2 and RST3, and pathogenicity on pumpkin leaves. All $X$. cucurbitae isolates tested were pathogenic on 'Howden' pumpkin. In total, 312 non-X. cucurbitae isolates were identified into 10 genera based on the restriction fragment length polymorphism analysis. None of the non- $X$. cucurbitae isolates was pathogenic on Howden. In vitro studies of interactions between non- $X$. cucurbitae and $X$. cucurbitae showed that Pantoea isolates had antagonistic activity against $X$. cucurbitae. Identified Pantoea agglomerans showed the highest antagonistic activity against $X$. cucurbitae.
\end{abstract}

Pumpkin (Cucurbita pepo L. and C. moschata (Duchesne) Duchesne ex Poir) and squash (C. pepo, C. moschata, and C. maxima Duch.) are grown worldwide for food and as ornamentals (Anonymous 2015; Whitaker and Bemis 1975). The United Stated is one of the leading countries in the world in pumpkin and squash production (USDA-NASS 2015). The North Central region (NCR) of the United States produces more than $90 \%$ of processing pumpkin and considerable jack-o-lantern pumpkin and summer and winter squash (USDA-NASS 2015). Illinois, with approximately 10,000 ha of pumpkin, is the leading state in pumpkin production in the nation (Ravanlou and Babadoost 2015).

Pumpkin and squash are infected by several bacterial, fungal, viral, and nematode pathogens (Zitter et al. 1996). Xanthomonas cucurbitae, Pseudomonas syringae pv. lachrymans, Erwinia tracheiphila, and Serration marcencens, the causal agents of bacterial spot (also known as bacterial leaf spot), angular leaf spot, bacterial wilt, and cucurbit yellow vine, respectively, are major bacterial diseases in the NCR (Babadoost and Zitter 2009; Babadoost et al. 2004, 2012). Bacterial spot and angular leaf spot are the most common bacterial diseases in the NCR and both diseases affect leaves and fruit of cucurbits (Babadoost et al. 2004). Bacterial spot has been reported on leaves and fruit of pumpkin in Illinois and some other states (Babadoost et al. 2012; Ravanlou and Babadoost 2015) but the occurrence and importance of angular leaf spot on pumpkin and squash, especially on pumpkin and squash fruit, need to be investigated.

Bacterial spot of cucurbits, caused by X. cucurbitae (ex Bryan) Vauterin et al. (syn. X. campestris (Pammel) Dowson pv. cucurbitae (Bryan) Dye) (Rademaker et al. 2005), has become one of the most important diseases of pumpkin and winter squash in Illinois and some other cucurbit-growing areas in the United States (Babadoost et al. 2012; Ravanlou and Babadoost 2015). This disease was first

Corresponding author: M. Babadoost; E-mail: babadoos@illinois.edu

Accepted for publication 25 July 2016.

http://dx.doi.org/10.1094/PDIS-01-16-0107-RE

(C) 2016 The American Phytopathological Society reported as bacterial leaf spot on 'Hubbard' squash in New York in 1926 (Bryan 1930). Subsequently, the disease was identified in other cucurbit-growing areas in Asia, Australia, Europe, and North America on cucumber, pumpkin, squash, and watermelon (Bineeta et al. 1999; Dutta et al. 2013b; Lamichhane et al. 2010; Pruvost et al. 2008, 2009; Williams and Zitter 1996).

$X$. cucurbitae infects leaves and fruit of cucurbit crops (Ravanlou and Babadoost 2015; Saddler and Bradbury 2005; Williams and Zitter 1996). Symptoms on the leaves of pumpkin and squash are small ( 2 to $4 \mathrm{~mm}$ ), chlorotic to beige spots (Ravanlou and Babadoost 2015; Williams and Zitter 1996). As lesions coalesce, they may appear more angular and similar to the spots caused by $P$. syringae pv. lachrymans (Williams and Zitter 1996). On fruit, small, slightly sunken, circular spots, 1 to $3 \mathrm{~mm}$ in diameter, with a beige center and dark-brown halo develop. Later, the spots may be colonized by secondary fungi and bacteria (Babadoost and Zitter 2009; Williams and Zitter 1996). As the disease develops, the lesions enlarge, reaching 10 to $15 \mathrm{~mm}$ in diameter, and the cuticle and epidermis may crack. Infection on fruit causes penetration of bacteria into the flesh, leading to significant fruit rot either in the field or, later, in storage (Babadoost and Zitter 2009).

$X$. cucurbitae is an aerobic, gram-negative, nonspore-forming rod bacterium. Its cells measure 0.5 to 1.3 by 0.4 to $0.6 \mu \mathrm{m}$. X. cucurbitae develops characteristic yellow, convex, shiny and mucoid colonies on yeast extract-dextrose- $\mathrm{CaCO}_{3}$ (YDC) agar medium (Schaad et al. 2001).

Angular leaf spot, caused by Pseudomonas syringae van Hall pv. lachrymans (Smith and Bryan) Young et al., is a widespread bacterial disease of cucurbits throughout the world, most seriously affecting cucumber (Williams 1996). The bacterium attacks the leaves, stems, and fruit of cucurbit plants. On leaves, the bacterium causes small, angular, water-soaked areas, which gradually become brown. Leaf lesions are delimited by the veins and, hence, have the angular appearance. Under humid conditions, a white, milky exudate forms on the lesions and dries to form a thin, white crust. Affected leaf tissue often dries and drops out, leaving irregularly shaped holes in the leaves. Heavily infected leaves may turn yellow. Lesions may also develop on petioles, stems, and fruit, on which the white, crusty exudates can also be evident (Williams 1996). On fruit, lesions appear as 
small, circular, water-soaked spots, 1 to $3 \mathrm{~mm}$ in diameter, often with a light tan center. Fruit rot may follow the infection.

P. syringae pv. lachrymans is an aerobic, gram-negative, nonsporeforming rod, measuring 0.8 by 1 to $2 \mu \mathrm{m}$ and motile, with one to five polar flagella. This bacterium produces a diffusible green fluorescent pigment on suitable culture media, such as King's B medium (KB) (Schaad et al. 2001). P. syringae pv. lachrymans is distinguished from other $P$. syringae pathovars primarily by its host range on cucurbits (Williams 1996).

Because foliar and fruit symptoms caused by $X$. cucurbitae and $P$. syringae pv. lachrymans on cucurbits are reported to be similar (Balaž et al. 2014; Hansen 2009; Williams 1996; Williams and Zitter 1996), diagnosing bacterial spot from angular leaf spot in pumpkin and squash, especially on fruit, is a challenging task. In the past 10 years, fruit bacterial spot has been observed in many pumpkin and winter squash fields in the NCR. This study was conducted to (i) survey pumpkin and winter squash fields in the NCR to determine the incidence and severity of fruit bacterial spot and (ii) identify bacteria associated with the bacterial spot.

\section{Materials and Methods}

Field survey. During 2011 to 2013, field surveys were conducted to assess occurrence of bacterial spot on fruit of pumpkin and winter squash fields in the NCR. Each year, at least five commercial pumpkin and squash fields in each state were visited within 3 weeks of harvest during September and October, when fruit were ripe. The following fields were surveyed: in 2011, 68 pumpkin fields in eight states (Illinois, Indiana, Iowa, Kansas, Missouri, Nebraska, Ohio, and Wisconsin); in 2012, 87 fields, including 51 pumpkin and 36 squash fields, in eight states (Illinois, Indiana, Iowa, Kansas, Michigan, Missouri, Ohio, and Wisconsin); and, in 2013, 90 fields, including 68 pumpkin and 22 squash fields, in nine states (Illinois, Indiana, Iowa, Kansas, Michigan, Missouri, Nebraska, Ohio, and Wisconsin). In each field, 12 locations on an M-shaped path were selected and, at each location, five fruit were randomly chosen to evaluate for incidence and severity of bacterial spot on fruit. Incidence of fruit with bacterial spot in each field was calculated as percentage of symptomatic fruit over total 60 fruit inspected. The severity of the disease was calculated as average of percent affected areas of fruit surface.

Isolation and maintenance of bacteria associated with infected tissues. Fruit samples collected from commercial fields were processed for isolation of bacteria within 3 days from sample collection. For isolating bacteria, soil adhered to the fruit was removed by washing under tap water. The infected area of fruit was disinfested by rubbing with a paper towel soaked in $75 \%$ ethanol. Three or four suspected bacterial lesions on each fruit were cut (approximately 5 by 5 by $5 \mathrm{~mm}$ of tissue) with a sterilized razor blade and the tissue was inserted into a microcentrifuge tube containing $1 \mathrm{ml}$ of sterilized distilled water (SDW). The tube was then vortexed for $30 \mathrm{~s}$ to release bacterial cells from fruit tissue into water. For each sample, a loop-full of bacterial suspension was streaked onto each of three different culture media, including Luria-Bertani agar medium (LB), YDC, and $\mathrm{KB}$ in $100-\mathrm{mm}$ petri plates (Schaad et al. 2001) to collect as many associated bacterial isolates as possible. Culture plates were incubated in darkness at $24 \pm 1{ }^{\circ} \mathrm{C}$ for 48 to $72 \mathrm{~h}$. Single-celled colonies were picked and subcultured on the same culture media at least twice before long-term storage. Purified isolates were then transferred into 1.5 - $\mathrm{ml}$ microcentrifuge tubes containing 15 and $30 \%$ glycerol in SDW and maintained at -20 and $-80^{\circ} \mathrm{C}$, respectively (Babadoost and Ravanlou 2012).

Identification of $\boldsymbol{X}$. cucurbitae isolates. $X$. cucurbitae isolates were identified based on their colony characteristics and polymerase chain reaction (PCR) test. Characteristic mucoid, yellow colonies on culture plates were selected as suspected $X$. cucurbitae isolates. First, purified $X$. cucurbitae candidates were streaked onto YDC ( $10 \mathrm{~g}$ of yeast extract, $20 \mathrm{~g}$ of dextrose, $20 \mathrm{~g}$ of calcium carbonate, and $15 \mathrm{~g}$ of agar in $1,000 \mathrm{ml}$ distilled water) and incubated at $24 \pm 1^{\circ} \mathrm{C}$ for 48 to $72 \mathrm{~h}$. Developed characteristic convex, mucoid, and yellow colonies were compared with American Type Culture Collection (ATCC) X. cucurbitae strain 23378, which was served as the positive control in this study.
Bacterial isolates were grown on YDC for $48 \mathrm{~h}$ at $24 \pm 1^{\circ} \mathrm{C}$ for PCR tests. Using a toothpick, cells of each bacterial isolate were transferred into a $1.5 \mathrm{ml}$ microcentrifuge tube containing $1 \mathrm{ml}$ of SDW. Bacterial suspension with $1.0 \times 10^{9} \mathrm{CFU} / \mathrm{ml}$ was prepared. Xanthomonas genus specific primers, RST2 (5'-AGGCCCTGGAA GGTGCCCTGGA-3') and RST3 (5'-ATCGCACTGCGTACCGCG CGCGA-3'), which amplify partial hrpB5 and hrpB6 regions, were used (Leite et al. 1994). A $25-\mu 1$ reaction volume was prepared, which contained $12.5 \mu \mathrm{l}$ of $2 \times$ Gotaq Green Master Mix (Promega Corporation, Madison, WI), $1 \mu \mathrm{l}$ of each primer, $10 \mu \mathrm{l}$ of nucleasefree water, and $0.5 \mu \mathrm{l}$ of bacterial suspension $\left(10^{9} \mathrm{CFU} / \mathrm{ml}\right)(\mathrm{Meng}$ et al. 2004; Zhao et al. 2002). PCR amplification was performed using a thermal cycler machine (Model PCT-200; MJ Research Inc., Waltham, MA), with initial denaturation at $95^{\circ} \mathrm{C}$ for $10 \mathrm{~min} ; 32$ cycles of denaturing at $95^{\circ} \mathrm{C}$ for $40 \mathrm{~s}$, annealing at $59^{\circ} \mathrm{C}$ for $40 \mathrm{~s}$, and extension at $72^{\circ} \mathrm{C}$ for $1 \mathrm{~min}$; followed by a final extension step at $72^{\circ} \mathrm{C}$ for $10 \mathrm{~min}$. To visualize the amplicon, $6 \mu \mathrm{l}$ of the resulting product was run in $1 \%$ agarose gel containing SYBR Safe DNA Gel Stain (Thermo Fisher Scientific, Inc., Carlsbad, CA) at $100 \mathrm{~V}$ for $30 \mathrm{~min}$, and visualized under Blue-light Transilluminator (Thermo Fisher Scientific, Inc.). A 1-kb DNA ladder was also loaded on the gel to determine the size of amplicons. An amplicon with the size of 1,400 bp was delineated for each positive isolate.

Identification of non- $\boldsymbol{X}$. cucurbitae bacteria. All of the isolates not suspected as $X$. cucurbitae were considered as non-X. cucurbitae and selected for identification, determination of pathogenicity, and interactions with $X$. cucurbitae. Identification of non-X. cucurbitae isolates was at the genus level and was achieved by using the restriction fragment length polymorphism (RFLP) analysis. In total, 312 isolates, including 208 and 104 isolates from 2012 and 2013, respectively, were selected for this study. The isolates were cultured on LB and incubated at $24 \pm 1^{\circ} \mathrm{C}$ for 48 to $72 \mathrm{~h}$. A loop-full of bacterial cells were transferred into a $1.5-\mathrm{ml}$ microcentrifuge tube containing $1 \mathrm{ml}$ of SDW. Bacterial cells were suspended and adjusted to $1.0 \times$ $10^{9} \mathrm{CFU} / \mathrm{ml}$. PCR amplification was performed to amplify the $16 \mathrm{~S}$ ribosomal RNA (rRNA) genes of selected bacterial isolates using the primer set 27f (5'-AGAGTTTGATCMGGCTCAG-3') and 1492r (5'-GGTTACCTTGTTACGACT T-3') (Lane 1991). A 50- $\mu$ l reaction volume was prepared, which contained $25 \mu \mathrm{l}$ of $2 \times$ Gotaq Green Master Mix (Promega Corporation), $2 \mu \mathrm{l}$ of each primer, $20 \mu \mathrm{l}$ of nuclease-free water, and $1 \mu l$ of bacterial suspension $(1.0 \times$ $10^{9} \mathrm{CFU} / \mathrm{ml}$ ) (Meng et al. 2004; Zhao et al. 2002). Cycling conditions for PCR (Model PCT-200; MJ Research Inc.) included initial incubation at $95^{\circ} \mathrm{C}$ for $2 \mathrm{~min} ; 35$ cycles of DNA denaturation at $94^{\circ} \mathrm{C}$ for $45 \mathrm{~s}$, primer annealing at $55^{\circ} \mathrm{C}$ for $30 \mathrm{~s}$, and DNA elongation at $72^{\circ} \mathrm{C}$ for $1.5 \mathrm{~min}$; followed by final extension at $72^{\circ} \mathrm{C}$ for $5 \mathrm{~min}$. The PCR product $(6 \mu \mathrm{l})$ was run in $1 \%$ agarose gel containing SYBR Safe DNA Gel Stain (Thermo Fisher Scientific Inc.) at $100 \mathrm{~V}$ for $30 \mathrm{~min}$ and visualized as described above. The rest of the PCR products $(44 \mu \mathrm{l})$ were then purified with the Wizard SV gel and PCR Clean-Up kit (Promega Corporation) according to the manufacturer's instructions. Restriction enzyme HaeIII was used to digest purified PCR product at $37^{\circ} \mathrm{C}$ for $1 \mathrm{~h}$ (Life Technologies, Carlsbad, CA). Digestion was terminated by incubating at $80^{\circ} \mathrm{C}$ for $20 \mathrm{~min}$. Purified PCR products were digested according to the manufacturer's instructions. The digested DNA was loaded in $4 \%$ agarose gel stained with SYBR Safe DNA Gel Stain at $100 \mathrm{~V}$ for $2 \mathrm{~h}$ with a $1-\mathrm{kb}$ DNA ladder as a marker, and visualized under Blue-light Transilluminator (Clare Chemical Research, Inc., Dolores, CO). RFLP analysis was performed at least twice for each isolate. The non-X. cucurbitae isolates were grouped based on their RFLP patterns, and the 16s rRNA gene of the representative isolates were sequenced ( $\mathrm{Yu}$ and Babadoost 2013). Obtained 16s rRNA sequences were subjected to nucleotide blast in the National Center for Biotechnology Information (NCBI) and identified to the genus level.

Pathogenicity test. 'Howden', a pumpkin cultivar susceptible to $X$. cucurbitae and $P$. syringae pv. lachrymans, was used for the pathogenicity test of isolated bacteria. Bacterial isolates tested for their pathogenicity included 255 isolates of $X$. cucurbitae, 20 isolates of Pseudomonas, and four isolates of each of the other collected genera. Each isolate of bacteria was cultured on LB at $24 \pm 1^{\circ} \mathrm{C}$ for $72 \mathrm{~h}$. The 
inoculum was prepared by washing bacterial colonies with SDW from agar medium into a 15-ml conical tube (Thermo Scientific Inc.). The conical tube was then vortexed for $30 \mathrm{~s}$. Cell density in each inoculum suspension was measured by spectrophotometer (Smart Spec 3000; Bio-Rad, Philadelphia) at an optical density at $600 \mathrm{~nm}=0.5$. Cell concentration was then adjusted to $1.0 \times 10^{8} \mathrm{CFU} / \mathrm{ml}$. In this inoculation, $X$. cucurbitae ATCC strain 23378 and $P$. syringae pv. lachrymans ATCC strain 7386 were included as positive controls and SDW was included as a negative control. Inoculation was carried out using a revised syringe pressure infiltration method combining two inoculation methods developed by Barak et al. (2001) and Katagiri et al. (2002). For each isolate, two leaves from the same 20-day-old asymptomatic pumpkin plant were inoculated on the abaxial side by three infiltrations per leaf. In each infiltration, approximately $10 \mu \mathrm{l}$ of inoculum was deposited. Inoculated plants were maintained in a greenhouse at $26 \pm$ $2^{\circ} \mathrm{C}$. Development of spots on leaves was monitored and recorded after $1,3,5$, and 7 days postinoculation. Symptomatic leaves were then collected from plants in the greenhouse and processed for bacterial isolation. Isolated $X$. cucurbitae was then identified by characteristic yellow mucoid colonies on YDC and the PCR test, as previously described (Leite et al. 1994; Mohammadi et al. 2001).

In vitro study of interactions between non- $X$. cucurbitae and $X$. cucurbitae bacteria. To determine antagonistic interactions between non- $X$. cucurbitae isolates and $X$. cucurbitae, a modified method described by Long et al. (2005) was used. The X. cucurbitae strain 23378 from ATCC, representative $X$. cucurbitae from NCR, and one representative non- $X$. cucurbitae isolate from each of 10 identified genera were cultured on $\mathrm{LB}$ and incubated at $24 \pm 1{ }^{\circ} \mathrm{C}$ in the dark for 48 to $72 \mathrm{~h}$. Bacterial cells were washed from LB into a $15-\mathrm{ml}$ conical tube containing $10 \mathrm{ml}$ of SDW. The conical tube was then vortexed for $30 \mathrm{~s}$ to make a homogenous bacterial suspension. Cell density in each suspension was measured by spectrophotometer, as described above. Cell concentration was then adjusted to $8 \times 10^{8} \mathrm{CFU} / \mathrm{ml}$. A suspension $(50 \mu \mathrm{l})$ of $X$. cucurbitae ATCC strain 23378 or $X$. cucurbitae isolate from the NCR was added onto LB and evenly spread using a flame-sterilized glass rod. Four circular filter papers (10 mm in diameter; GE Healthcare Life Sciences, Pittsburgh) soaked in non-X. cucurbitae suspension were placed on the top of LB medium with $X$. cucurbitae. Filter paper soaked in SDW was used as a negative control. Each interaction treatment had three replications. The plates were then incubated at $24 \pm 1^{\circ} \mathrm{C}$ for $72 \mathrm{~h}$. Antagonistic interaction was assessed by the width of the inhibition zone of $X$. cucurbitae development on LB medium around the filter papers. After observing antagonistic effects of the Pantoea isolate toward $X$. cucurbitae, five more isolates from genus Pantoea were tested for their interactions with $X$. cucurbitae. The tests were repeated twice.

\section{Results}

Symptoms on pumpkin and squash fruit. The most common symptom on pumpkin and squash fruit was small lesions (1 to $5 \mathrm{~mm}$ in diameter), with a beige center and yellow or brown halo (Figs. 1 and 2). Color and size of the lesions varied by plant species and cultivar. In jack-o-lantern pumpkin 'Wolf' ( $C$. pepo), fruit lesions were 1 to $4 \mathrm{~mm}$ in diameter, sunken, with a beige center and light-brown halo (Fig. 1A). Similarly, in processing pumpkin 'Dickinson' (C. moschata), lesions were 1 to $4 \mathrm{~mm}$ in diameter, water-soaked, with a beige center and light-brown halo (Fig. 1B). In squash cultivars, four different kinds of lesions were observed (Fig. 2). In Hubbard squash (C. maxima), lesions were 1 to $2 \mathrm{~mm}$ in diameter, sunken, with a gray center and dark-green halo (Fig. $2 \mathrm{~A}$ ); in 'Butternut' (C. moschata), lesions were 1 to $5 \mathrm{~mm}$ in diameter, with a beige center and brown halo (Fig. 2B); in 'Speckled Hound' (C. maxima), fruit lesions were 1 to $5 \mathrm{~mm}$ in diameter, with a beige center and dark-red halo (Fig. 2C); and in 'Spaghetti' squash (C. pepo), lesions were 1 to $6 \mathrm{~mm}$ in diameter, with a beige center and dark-brown halo (Fig. 2D). The rind in some lesions of Butternut, Speckled Hound, and Spaghetti squash was cracked (Fig. 2).

Occurrence of bacterial spot in pumpkin and squash fields. Bacterial spot was observed in pumpkin and winter squash fields in all nine states in the NCR visited in 2011, 2012, and 2013 (Tables 1 and 2). Fruit with bacterial spot were observed in 57 of $68(83.8 \%)$, 46 of 51 (90.2\%), and 62 of 68 (91.2\%) pumpkin fields in 2011, 2012, and 2013, respectively (Table 1). Similarly, fruit with bacterial spot were in 33 of $36(91.7 \%)$ and 19 of $22(86.4 \%)$ winter squash fields in 2012 and 2013, respectively (Table 2).

The incidence of fruit with bacterial spot in pumpkin fields with the symptomatic fruit ranged from 3.3 to $98.3 \%$ (average $32.3 \%$ ), 1.7 to $96.7 \%$ (average $33.6 \%$ ), and 1.7 to $93.3 \%$ (average $27.8 \%$ ) in 2011 , 2012, and 2013, respectively (Table 1). The average incidence of the infected fruit in all fields surveyed was $27.1,30.3$, and $25.3 \%$ in 2011,2012 , and 2013, respectively. Severity of bacterial spot on fruit in pumpkin fields with the infected fruit ranged from 1.0 to $4.1 \%$ (average 1.3\%), 1.0 to $7.0 \%$ (average $1.5 \%$ ), and 1.0 to $2.1 \%$ (average $1.1 \%$ ) in 2011,2012 , and 2013, respectively (Table 1 ). The average severity of bacterial spot on fruit in all pumpkin fields surveyed was 1.1, 1.3 , and $1.0 \%$ in 2011, 2012, 2013, respectively. The incidence of fruit with bacterial spot in squash fields with the symptomatic fruit ranged from 3.3 to $78.3 \%$ (average $22.0 \%$ ) in 2012 and from 1.7 to $48.3 \%$ (average 19.6\%) in 2013 (Table 2). The average incidence of the symptomatic fruit in all fields surveyed was $20.2 \%$ in 2012 and $16.9 \%$ in 2013. Severity of bacterial spot in squash fields with symptomatic fruit ranged from 1.0 to $2.8 \%$ (average 1.2\%) in 2012 and from 1.0 to $1.7 \%$ (average 1.1\%) in 2013 (Table 2). The average severity of bacterial spot on fruit in all squash fields surveyed was 1.1\% in 2012 and $1.0 \%$ in 2013.

Isolated bacteria. $X$. cucurbitae and non- $X$. cucurbitae bacteria were isolated from all symptomatic fruit collected. In total, 1,381 isolates, including 1,042 isolates from pumpkin fruit and 339 isolates from squash fruit, were purified and 255 X. cucurbitae isolates and 312 non- $X$. cucurbitae isolates were tested.

Identification of $X$. cucurbitae. $X$. cucurbitae isolates developed characteristic mucoid, convex, and yellow-green colonies on YDC. The isolates produced a 1,400-bp amplicon in PCR tests, which was the same as the amplicon produced by the ATCC strain 23378.
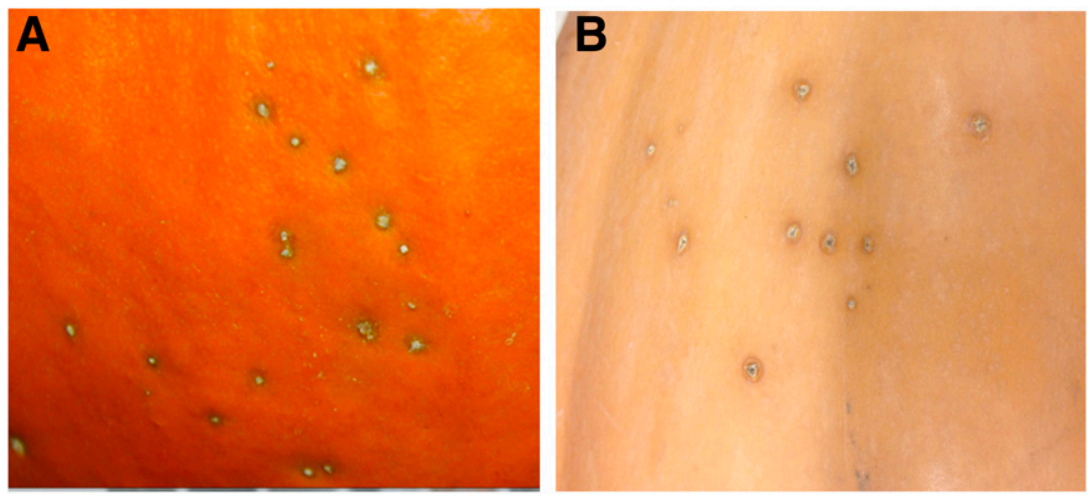

Fig. 1. Spots caused by Xanthomonas cucurbitae on pumpkin fruit in the North Central region of the United States. A, Sunken lesions with beige center and dark-brown halo on a fruit of jack-o-lantern pumpkin (Cucurbita pepo Wolf); and B, lesions with a beige center and light-brown halo on a fruit of processing pumpkin (Cucurbita moschata Dickinson). 


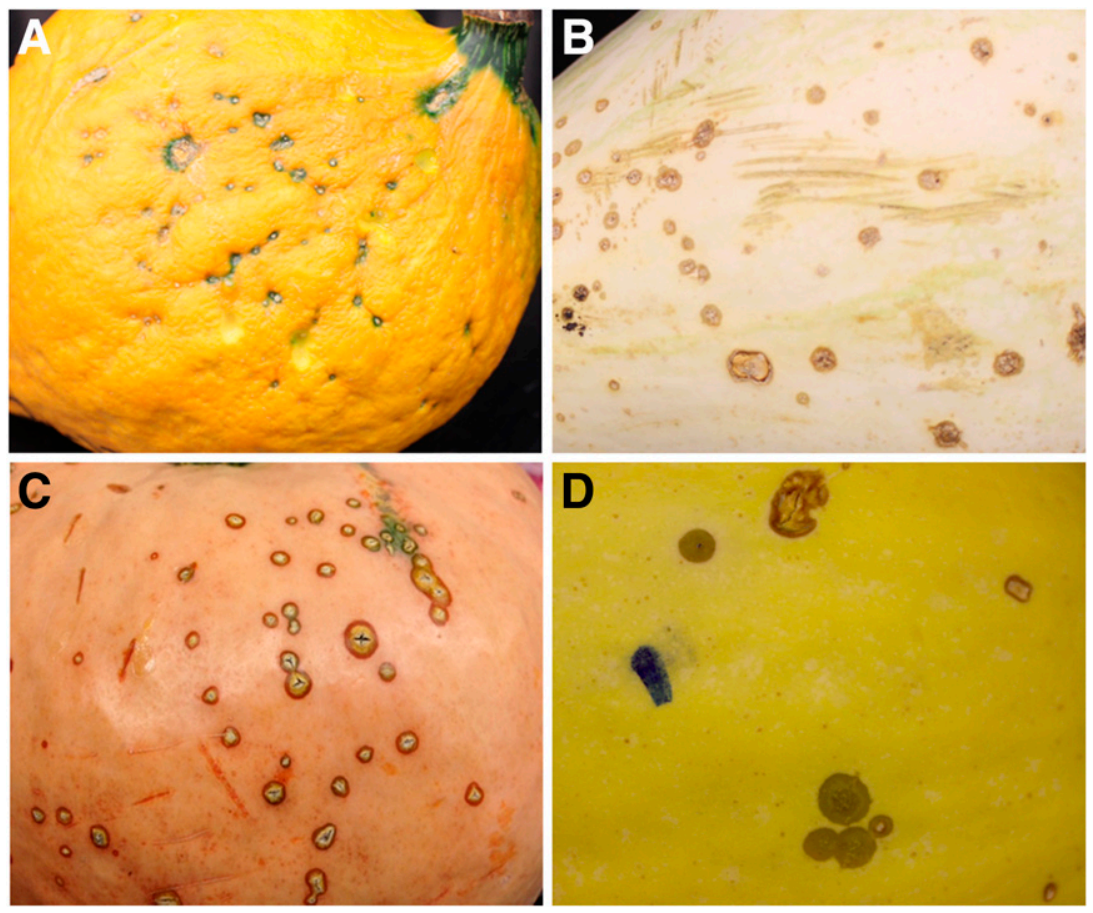

Fig. 2. Spots caused by Xanthomonas cucurbitae on squash fruit in the North Central region of the United States. A, Water soaked lesions with a beige center and dark-green halo on 'Hubbard' squash (Cucurbita maxima); B, lesions with a cracked beige center and light-brown halo on 'Butternut' squash (C. moschata); C, lesions with a cracked beige center and dark-red halo on 'Speckled Hound' squash (C. maxima); and D, lesions with a beige center and dark-brown halo on 'Spaghetti' squash (C. pepo).

Table 1. Incidence and severity of fruit bacterial spot in pumpkin fields in the North Central region ${ }^{\mathrm{a}}$

\begin{tabular}{|c|c|c|c|c|c|c|c|c|}
\hline \multirow[b]{2}{*}{ Year, state } & \multicolumn{2}{|c|}{ Number of fields } & \multicolumn{3}{|c|}{ Incidence of infected fruit $(\%)^{b}$} & \multicolumn{3}{|c|}{ Severity of fruit infection $(\%)^{\mathrm{c}}$} \\
\hline & Surveyed $^{\mathrm{d}}$ & With infected fruit & Lowest & Highest & Average & Lowest & Highest & Average \\
\hline \multicolumn{9}{|l|}{2011} \\
\hline Illinois & 22 & 19 & 3.3 & 81.7 & 22.4 & 1.0 & 2.4 & 1.3 \\
\hline Indiana & 7 & 7 & 20.0 & 98.3 & 61.4 & 1.1 & 4.1 & 1.8 \\
\hline Iowa & 8 & 4 & 8.3 & 28.3 & 16.3 & 1.0 & 1.3 & 1.1 \\
\hline Kansas & 5 & 5 & 15.0 & 51.7 & 29.7 & 1.0 & 1.4 & 1.1 \\
\hline Missouri & 6 & 3 & 6.7 & 56.7 & 28.3 & 1.2 & 1.9 & 1.6 \\
\hline Nebraska & 5 & 5 & 6.7 & 93.3 & 54.3 & 1.0 & 1.5 & 1.3 \\
\hline Ohio & 9 & 9 & 6.7 & 76.7 & 32.0 & 1.0 & 1.8 & 1.3 \\
\hline Wisconsin & 6 & 5 & 5.0 & 40.0 & 21.3 & 1.0 & 1.2 & 1.1 \\
\hline Total or average & 68 & 57 & 3.3 & 98.3 & 32.3 & 1.0 & 4.1 & 1.3 \\
\hline \multicolumn{9}{|l|}{2012} \\
\hline Illinois & 15 & 13 & 1.7 & 56.7 & 23.7 & 1.0 & 7.0 & 2.0 \\
\hline Indiana & 7 & 7 & 13.3 & 96.7 & 59.8 & 1.0 & 2.5 & 1.7 \\
\hline Iowa & 3 & 3 & 6.7 & 50.0 & 21.1 & 1.0 & 1.2 & 1.1 \\
\hline Kansas & 5 & 5 & 8.3 & 21.7 & 14.0 & 1.0 & 1.0 & 1.0 \\
\hline Michigan & 4 & 2 & 8.3 & 14.0 & 11.2 & 1.0 & 1.1 & 1.1 \\
\hline Missouri & 2 & 1 & 81.7 & 81.7 & 81.7 & 1.1 & 1.1 & 1.1 \\
\hline Ohio & 12 & 12 & 15.0 & 91.7 & 44.9 & 1.0 & 1.7 & 1.1 \\
\hline Wisconsin & 3 & 3 & 16.7 & 40.0 & 25.0 & 1.1 & 1.3 & 1.2 \\
\hline Total or average & 51 & 46 & 1.7 & 96.7 & 33.6 & 1.0 & 7.0 & 1.5 \\
\hline \multicolumn{9}{|l|}{2013} \\
\hline Illinois & 16 & 16 & 1.7 & 83.3 & 21.0 & 1.0 & 2.7 & 1.3 \\
\hline Indiana & 8 & 6 & 5.0 & 76.7 & 24.2 & 1.0 & 1.2 & 1.0 \\
\hline Iowa & 5 & 5 & 1.7 & 35.0 & 16.3 & 1.0 & 1.1 & 1.0 \\
\hline Kansas & 6 & 6 & 13.3 & 61.7 & 40.3 & 1.0 & 1.4 & 1.1 \\
\hline Michigan & 10 & 6 & 1.7 & 36.7 & 22.2 & 1.0 & 1.1 & 1.0 \\
\hline Missouri & 3 & 3 & 16.7 & 30.0 & 21.7 & 1.0 & 1.1 & 1.0 \\
\hline Nebraska & 6 & 6 & 3.3 & 16.7 & 8.3 & 1.0 & 1.0 & 1.0 \\
\hline Ohio & 10 & 10 & 18.3 & 93.3 & 53.7 & 1.0 & 1.9 & 1.3 \\
\hline Wisconsin & 4 & 4 & 13.3 & 66.7 & 32.9 & 1.0 & 1.1 & 1.0 \\
\hline Total or average & 68 & 62 & 1.7 & 93.3 & 27.8 & 1.0 & 2.7 & 1.1 \\
\hline
\end{tabular}

a In each field, 60 fruit at 12 locations were inspected for the presence of symptomatic fruit. Average = average of fields with symptomatic fruit.

${ }^{\mathrm{b}}$ Percentage of symptomatic fruit over 60 fruit inspected in each field.

${ }^{c}$ Percentage of fruit surface with bacterial spot. Data represent disease severity in 60 fruit in each field.

${ }^{\mathrm{d}}$ Fields were surveyed within 3 weeks of fruit harvest during September and October. 
In pathogenicity tests, plants infiltrated with SDW did not develop any lesions, and no bacterium was detected in the infiltrated tissues with SDW. However, pumpkin leaves inoculated with $X$. cucurbitae isolates from the NCR developed lesions with a yellow halo 7 days after inoculation. Plants inoculated with ATCC strain 23378 also developed lesions with a yellow halo. X. cucurbitae was isolated from plants inoculated with either the $X$. cucurbitae isolates from the NCR or ATCC strain 23378.

Identification of non- $X$. cucurbitae bacteria. In the RFLP analysis, 312 non- $X$. cucurbitae isolates were selected and 17 patterns were observed from digested $16 \mathrm{~S}$ rRNA fragments. In total, 51 representative non- $X$. cucurbitae isolates were subjected to $16 \mathrm{~S}$ rRNA gene sequencing and the sequences were then subjected to nucleotide blast in NCBI and grouped into 10 genera, including Arthrobacter, Enterobacter, Enterococcus, Erwinia, Exiguobacterium, Microbacterium, Pantoea, Peanibacillus, Pectobacterium, and Pseudomonas. The majority of the isolates were identified as Erwinia, Pantoea, Peanibacillus, and Pseudomonas spp. (Table 3).

Pathogenicity test of non-X. cucurbitae bacteria. None of the plants inoculated with the non- $X$. cucurbitae isolates developed lesions. A hypersensitive response was observed in the plants inoculated with isolates from Enterobacter, Pectobacterium, and Pseudomonas genera within $48 \mathrm{~h}$ after inoculation. Plants inoculated with $P$. syringae pv. lachrymans ATCC strain 7386 developed lesions in leaves. $P$. syringae pv. lachrymans was isolated from inoculated plants but none of the non-X. cucurbitae bacteria were isolated from infiltrated leaves 10 days after inoculation.

Interactions between non- $X$. cucurbitae and $X$. cucurbitae isolates. Inhibition zones were exclusively observed in the plates with Pantoea spp. and isolates of $X$. cucurbitae. Antagonistic effect was observed between three of six Pantoea isolates tested and $X$. cucurbitae. The inhibition zone developed by Pantoea isolates ranged from 1.5 to $10.5 \mathrm{~mm}$ (average $4.4 \mathrm{~mm}$ ) in width after $72 \mathrm{~h}$ of incubation. Two of the Pantoea isolates exhibited antagonistic activity against $X$. cucurbitae and were identified as Pantoea ananatis and P. agglomerans, based on the results of nucleotide blast of their 16S rRNA genes in NCBI, with a $\geq 98 \%$ identity score. The $P$. agglomerans isolate had the highest antagonistic effect against $X$. cucurbitae compared with the other Pantoea isolates. The inhibition zone developed by the $P$. agglomerans isolate ranged from 9.3 to $10.5 \mathrm{~mm}$ (average $10 \mathrm{~mm}$ ) in width after $72 \mathrm{~h}$ of incubation. The $P$. ananatis isolate developed an inhibition zone ranging from 1.5 to
$3 \mathrm{~mm}$ (average $1.6 \mathrm{~mm}$ ) in width after $72 \mathrm{~h}$ of incubation. The results were the average of the experiments.

\section{Discussion}

This study showed that bacterial spot is prevalent in pumpkin and winter squash fields in the NCR. The results of this study agree with the previous study (Ravanlou and Babadoost 2015), which reported bacterial spot incidence in more than $80 \%$ of pumpkin fields in Illinois. Similar reports have been published from other cucurbit-growing areas in the United States and other parts of the world (Babadoost and Zitter 2009; Dutta et al. 2013a,b; Pruvost et al. 2009; Trueman et al. 2014).

Bacterial spot was not a common disease in cucurbit crops in the NCR until 2006 but it has gradually become a serious threat to production of pumpkin and winter squash in this region and other cucurbit-growing areas (Babadoost and Zitter 2009; Babadoost et al. 2012). Since 2009, fruit losses caused by bacterial spot in some pumpkin and winter squash fields were so high that some of the pumpkin growers in Illinois and Nebraska ceased pumpkin and squash production (M. Babadoost, personal communications). Additional research is needed to determine the factors that resulted in widespread occurrence of bacterial spot in pumpkin and squash fields and occurrence of the disease on other cucurbit crops.

In this study, $X$. cucurbitae and non- $X$. cucurbitae bacteria were isolated form almost all symptomatic pumpkin and winter squash

Table 3. Non-Xanthomonas cucurbitae bacteria isolated from pumpkin and squash fruit with bacterial spot in the North Central region in 2012 and 2013

\begin{tabular}{lrr}
\hline & \multicolumn{2}{c}{ Number of isolates } \\
\cline { 2 - 3 } Bacterial genus & $\mathbf{2 0 1 2}$ & $\mathbf{2 0 1 3}$ \\
\hline Arthrobacter & 1 & 3 \\
Enterobacter & 7 & 1 \\
Enterococcus & 9 & 6 \\
Erwinia & 30 & 11 \\
Exiguobacterium & 8 & $-^{\mathrm{a}}$ \\
Microbacterium & 7 & 3 \\
Pantoea & 34 & 27 \\
Peanibacillus & 65 & 25 \\
Pectobacterium & 2 & 2 \\
Pseudomonas & 45 & 26 \\
Total & 208 & 104 \\
\hline
\end{tabular}

a No Exiguobacterium bacterium was identified from fruit in 2013.

Table 2. Incidence and severity of fruit bacterial spot in squash fields in the North Central region ${ }^{\mathrm{a}}$

\begin{tabular}{|c|c|c|c|c|c|c|c|c|}
\hline \multirow[b]{2}{*}{ Year, state } & \multicolumn{2}{|c|}{ Number of fields } & \multicolumn{3}{|c|}{ Incidence of infected fruit $(\%)^{b}$} & \multicolumn{3}{|c|}{ Severity of fruit infection $(\%)^{c}$} \\
\hline & Surveyed $^{d}$ & With infected fruit & Lowest & Highest & $\overline{\text { Average }}$ & Lowest & Highest & $\overline{\text { Average }}$ \\
\hline \multicolumn{9}{|l|}{$\overline{2012}$} \\
\hline Illinois & 9 & 8 & 8.0 & 60.0 & 23.1 & 1.0 & 2.0 & 1.5 \\
\hline Indiana & 3 & 3 & 45.0 & 53.3 & 48.3 & 1.1 & 1.4 & 1.3 \\
\hline Iowa & 11 & 11 & 3.3 & 38.3 & 11.5 & 1.0 & 1.1 & 1.0 \\
\hline Kansas & 5 & 5 & 8.3 & 30.0 & 19.7 & 1.0 & 2.8 & 1.4 \\
\hline Michigan & 1 & 1 & 3.3 & 3.3 & 3.3 & 1.0 & 1.0 & 1.0 \\
\hline Missouri & 3 & 2 & 55.0 & 78.3 & 66.7 & 1.1 & 1.7 & 1.4 \\
\hline Ohio & 1 & 1 & 18.3 & 18.3 & 18.3 & 1.1 & 1.1 & 1.1 \\
\hline Wisconsin & 3 & 2 & 3.3 & 13.3 & 8.3 & 1.0 & 2.8 & 1.3 \\
\hline Total or average & 36 & 33 & 3.3 & 78.3 & 22.0 & 1.0 & 2.8 & 1.2 \\
\hline \multicolumn{9}{|l|}{2013} \\
\hline Illinois & 5 & 4 & 1.7 & 46.7 & 21.3 & 1.0 & 1.5 & 1.1 \\
\hline Iowa & 3 & 3 & 13.3 & 33.3 & 20.6 & 1.0 & 1.0 & 1.0 \\
\hline Kansas & 4 & 4 & 11.7 & 48.3 & 28.3 & 1.0 & 1.7 & 1.3 \\
\hline Michigan & 3 & 2 & 1.7 & 18.3 & 10.0 & 1.0 & 1.0 & 1.0 \\
\hline Missouri & 2 & 2 & 16.7 & 18.3 & 17.5 & 1.0 & 1.0 & 1.0 \\
\hline Nebraska & 3 & 3 & 6.7 & 28.3 & 18.3 & 1.0 & 1.0 & 1.0 \\
\hline Wisconsin & 2 & 1 & 3.3 & 3.3 & 3.3 & 1.0 & 1.0 & 1.0 \\
\hline Total or average & 22 & 19 & 1.7 & 48.3 & 19.6 & 1.0 & 1.7 & 1.1 \\
\hline
\end{tabular}

${ }^{a}$ In each field, 60 fruit at 12 locations were inspected for the presence of symptomatic fruit. Average = average of fields with symptomatic fruit.

${ }^{b}$ Fields were surveyed within 3 weeks of fruit harvest during September and October.

c Percentage of symptomatic fruit over 60 fruit inspected in each field.

d Percentage of fruit surface with bacterial spot. Data represent disease severity in 60 fruit in each field. 
fruit. All tested X. cucurbitae isolates were pathogenic on pumpkin, and none of the non-X. cucurbitae isolates produced lesions on inoculated pumpkin plants. Thus, it was concluded that $X$. cucurbitae is the sole causal agent of the bacterial spot in pumpkin and squash fruit in the NCR. All collected Pseudomonas isolates were inoculated to 'Howden' pumpkin, a cultivar susceptible to Pseudomonas syringe pv. lachrymans, but none of them produced any lesions in the inoculated plants. Consequently, we concluded that non-X. cucurbitae bacteria isolated from pumpkin and winter squash fruit are either saprophytes or antagonists against $X$. cucurbitae.

Diagnosing bacterial spot (caused by $X$. cucurbitae) from angular leaf spot (caused by $P$. syringae pv. lachrymans) in cucurbits based on leaf or fruit symptoms is a challenging task (Babadoost and Zitter 2009; Balaž et al. 2014; Hansen 2009). No species-specific primer was available for identifying $X$. cucurbitae. However, we found that only $X$. cucurbitae produced a 1,400-bp amplicon with the Xanthomonasspecific primers RST2 and RST3, while other Xanthomonas spp. produce an 840-bp amplicon with RST2 and RST3 (Dutta et al. 2013a,b; Schaad et al. 2001). Thus, $X$. cucurbitae can be easily identified from non- $X$. cucurbitae bacteria and other Xanthomonas spp. by using primers RST2 and RST3. Overall, combined methods of observing colony characteristics of $X$. cucurbitae on YDC, PCR tests using primers RST2 and RST3, and pathogenicity tests on the susceptible pumpkin 'Howden' provide a reliable process for diagnosing bacterial spot caused by $X$. cucurbitae from other bacterial diseases of cucurbits.

In the in vitro tests, inhibition zones were exclusively observed in the LB plates with Pantoea ananatis and P. agglomerans against $X$. cucurbitae. Several Pantoea spp. have been identified as antagonistic to fungal and bacterial pathogens (Gent and Schwartz 2005; Vasebi et al. 2015; Zhang and Birch 1997). One of the Pantoea spp. best known as a biocontrol agent for control of plant disease is $P$. agglomerans, which has antibacterial activity against Erwinia amylovora (Kim et al. 2012). To our knowledge, this is the first report on antagonistic activity of Pantoea spp. against $X$. cucurbitae. Further investigations of the interactions between bacteria associated with bacterial spots on leaves and fruit of pumpkin and squash and X. cucurbitae may result in identifying a reliable biocontrol agent for managing bacterial spot of pumpkin and squash.

The existing methods for managing bacterial spot in cucurbits are to use copper compounds and some other fungicides, which are expected to suppress development of the disease. However, none of the copper compounds, biocontrol agents, and fungicides with potential effects on bacterial diseases was highly effective in reducing the incidence of bacterial spot in pumpkin in Illinois (Thapa 2014). Thus, developing effective strategies for managing bacterial spot in cucurbits is essential. Research for this purpose should focus on developing effective seed treatment for eradication of seedborne $X$. cucurbitae, determining pumpkin and squash cultivars resistant to bacterial spot, and developing reliable crop rotation.

\section{Literature Cited}

Anonymous. 2015. Cucurbita. Online publication. https://en.wikipedia.org/wiki/ Cucurbita

Babadoost, M., and Ravanlou, A. 2012. Outbreak of bacterial spot (Xanthomonas cucurbitae) in pumpkin fields in Illinois. Plant Dis. 96:1222.

Babadoost, M., Ravanlou, A., Egel, D. S., and O'Brien, D. 2012. Occurrence of bacterial spot (Xanthomonas cucurbitae) in pumpkin fields in the Midwest. (Abstr.) Phytopathology 102:S4.8.

Babadoost, M., Weinzierl, R. A., and Masiunas, J. B. 2004. Identifying and Managing Cucurbit Pests: Diseases, Insects, and Weeds. Univ. Ill. Publ. C1392. Urbana-Champaign, IL.

Babadoost, M., and Zitter, T. A. 2009. Fruit rot of pumpkin: A serious threat to the pumpkin industry. Plant Dis. 93:772-782.

Balaž, J., Iličić, R., Maširević, R., Jošić, D., and Kojić, S. 2014. First report of Pseudomonas syringae pv. syringae causing bacterial leaf spots of oil pumpkin (Cucurbita pepo) in Serbia. Plant Dis. 98:684.

Barak, J. D., Koike, S. T., and Gilberston, R. L. 2001. The role of crop debris and weeds in the epidemiology of bacterial leaf spot of lettuce in California. Plant Dis. 85:169-178.

Bineeta, S. B., Majumder, S., and Kumar, S. 1999. Fungal and bacterial diseases of cucurbits. Pages 251-252 in: Diseases of Horticultural Crops: Vegetables, Ornamentals and Mushrooms. L. R. Verma and R. C. Sharma, eds. Indus Publishing, New Delhi, India.
Bryan, M. K. 1930. Bacterial spot of squash. J. Agric. Res. 40:385-391.

Dutta, B., Gitaitis, R. D., Lewis, K. J., and Langston, D. B. 2013a. A new report of Xanthomonas cucurbitae causing bacterial spot of watermelon in Georgia, USA Plant Dis. 97:556.

Dutta, B., Gitaitis, R. D., Sanders, F. H., Booth, C., Smith, S., and Langston, D. B 2013b. First report of bacterial spot of pumpkin caused by Xanthomonas cucurbitae in Georgia, United States. Plant Dis. 97:1375.

Gent, D. H., and Schwartz, F. 2005. Management of Xanthomonas leaf blight of onion with a plant activator, biological control agent, and copper bactericides. Plant Dis. 89:631-639.

Hansen, M. A. 2009. Angular Leaf Spot of Cucumber. Online publication. Virginia Polytechnic Institute and State University. https://pubs.ext.vt.edu/450/450-700/ 450-700_pdf.pdf

Katagiri, F., Thilmony, R., and He, S. Y. 2002. The Arabidopsis thaliana-Pseudomonas syringae interaction. Arabidopsis Book 1:e0039.

Kim, I., Pusey, P. L., Zhao, Y., Korban, S. S., Choi, H., and Kim, K. K. 2012. Controlled release of Pantoea agglomerans E325 for biocontrol of fire blight disease of apple. J. Control. Release 161:109-115.

Lamichhane, J. R., Varvaro, L., and Balestra, G. M. 2010. Bacterial leaf spot caused by Xanthomonas cucurbitae reported on pumpkin in Nepal. New Dis. Rep. 22:20.

Lane, D. J. 1991. 16S/23S rRNA Sequencing. Pages 115 to 175 in: Nucleic Acid Techniques in Bacterial Systematics. E. Stackebrandt and M. Goodfellow, eds. J. Wiley and Sons Ltd., New York.

Leite, R. P., Jr., Minsavage, G. V., Bonas, U., and Stall, R. E. 1994. Detection and identification of phytopathogenic Xanthomonas strains by amplification of DNA sequences related to the hrp genes of Xanthomonas campestris pv. vesicatoria. Appl. Environ. Microbiol. 60:1068-1077.

Long, R. A., Rowley, D. C., Zamora, E., Liu, J., Bartlett, D. H., and Azam, F. 2005 Antagonistic interactions among marine bacteria impede the proliferation of Vibrio cholera. Appl. Environ. Microbiol. 71:8531-8536.

Meng, X. Q., Umesh, K. C., Davis, R. M., and Gilbertson, R. L. 2004. Development of PCR-based assays for detecting Xanthomonas campestris pv. carotae, the carrot bacterial leaf blight pathogen, from different substrates. Plant Dis. 88:1226-1234.

Mohammadi, M., Mirzaee, M. R., and Rahimian, H. 2001. Physiological and biochemical characteristics of Iranian strains of Xanthomonas axonopodis pv. citri, the causal agent of citrus bacterial canker disease. J. Phytopathol. 149:65-75.

Pruvost, O., Robene-Soustrade, I., Ah-You, N., Jouen, E., Boyer, C., Waller, F., and Hostachy, B. 2008. First report of Xanthomonas cucurbitae causing bacterial leaf spot of pumpkin on Reunion Island. Plant Dis. 92:1591.

Pruvost, O., Robène-Soustrade, I., Ah-You, N., Jouen, E., Boyer, C., Wuster, G., Hostachy, B., Napoles, C., and Dogley, W. 2009. First report of Xanthomonas cucurbitae causing bacterial leaf spot of watermelon in the Seychelles. Plant Dis. 93:671.

Rademaker, J. L. W., Louws, F. J., Schultz, M. H., Rossbach, U., Vauterin, L., Swings, J., and de Bruijn, F. J. 2005. A comprehensive species to strain taxonomic framework for Xanthomonas. Phytopathology 95:1098-1111.

Ravanlou, A., and Babadoost, M. 2015. Development of bacterial spot, incited by Xanthomonas cucurbitae, in pumpkin fields. HortScience 50:714-720.

Saddler, G. S., and Bradbury, J. F. 2005. Xanthomonadales. Pages 63-122 in Bergey's Manual of Systematic Bacteriology, 2nd ed. Springer, New York.

Schaad, N. W., Jones, J. B., and Lacy, G. H. 2001. Xanthomonas. Pages 175-200 in: Laboratory Guide for Identification of Plant Pathogenic Bacteria, 3rd ed. American Phytopathological Society, St. Paul, MN.

Thapa, S. 2014. Field survival of Xanthomonas cucurbitae, the causal agent of bacterial spot of pumpkin, and efficacy of selected chemicals and biocontrol agents for control of the diseases. MS dissertation, Department of Crop Sciences, University of Illinois at Urbana-Champaign, Urbana.

Trueman, C. L., Roddy, E., and Goodwin, P. H. 2014. First report of bacterial spot (Xanthomonas cucurbitae) of pumpkin in Ontario, Canada. New Dis. Rep. 30:8

USDA-NASS. 2015. Vegetables 2014 summary. Online publication. United States Department of Agriculture-National Agricultural Statistical Service. http:// usda.mannlib.cornell.edu/usda/nass/VegeSumm/2010s/2015/VegeSumm01-29-2015.pdf

Vasebi, Y., Alizadeh, A., and Safaie, N. 2015. Pantoea agglomerans ENA1 as biocontrol agent of Macrophomina phaseolina and growth enhancement of soybean. J. Crop. Prot. 4:43-57.

Whitaker, T., and Bemis, W. P. 1975. Origin and evolution of cultivated Cucurbita. Bull. Torrey Bot. Club 102:362-368.

Williams, P. H. 1996. Angular leaf spot. Pages 33-34 in: Compendium of Cucurbit Diseases. T. A. Zitter, D. L. Hopkins, and C. E. Thomas, eds. American Phytopathological Society, St. Paul, MN.

Williams, P. H., and Zitter, T. A. 1996. Bacterial leaf spot. Page 35 in: Compendium of Cucurbit Diseases. T. A. Zitter, D. L. Hopkins, and C. E. Thomas, eds. American Phytopathological Society, St. Paul, MN.

Yu, J. M., and Babadoost, M. 2013. Occurrence of Fusarium commune and F. oxysporum in horseradish roots. Plant Dis. 97:453-460.

Zhang, L., and Birch, R. G. 1997. Mechanisms of biocontrol by Pantoea dispersa of sugar cane leaf scald disease caused by Xanthomonas albilineans. J. Appl. Microbiol. 82:448-454.

Zhao, Y. F., Damicone, J. P., and Blender, C. L. 2002. Detection, survival, and sources of bacterial inoculums for bacterial diseases of leafy crucifers in Oklahoma. Plant Dis. 86:883-888

Zitter, T. A., Hopkins, D. L., and Thomas, C. E., eds. 1996. Compendium of Cucurbit Diseases. American Phytopathological Society, St. Paul, MN. 